\section{Anthropometric characteristics and somatotype of professional soccer players by position}

\section{Cavia $M M^{*}$, Moreno $A$, Fernández-Trabanco $B$, Carrillo $C$ and Alonso-Torre SR}

Nutrición y Bromatología, Facultad de Ciencias, Universidad de Burgos

\section{Abstract}

The anthropometric characteristics are decisive for an optimal physical level and, therefore, a good level in the game; and they can be different depending on the game position.

The aim of this study was to identify the physical characteristics, body composition and somatotype of professional soccer players and to verify differences according to their playing positions: goalkeepers, defenders, forwards and midfielders.

The measurements were performed on 57 male players of a soccer team of the Spanish Football League One. Twenty seven anthropometric variables were measured (height and body weight, four bone breadths, eleven girths and ten skinfolds) and the Bioelectrical Impedance Analysis was also performed. The percentage of body fat has been determined from 11 different equations.

Goalkeepers showed the highest weight $(80.2 \pm 3.2 \mathrm{~kg})$, supraespinal $(10.5 \pm 3.8 \mathrm{~mm})$ and abdominal $(15.6 \pm 3.5 \mathrm{~mm})$ skinfolds than others positions. In relation to body fat percentages, similar results were obtained from the equations of Jackson-Pollock (from 3 and 7 skinfolds), Carter, Withers, and Heyward and Stolarczyk (mean value $7.8 \pm 1.5 \%$ ). Higher results were obtained from the other equations applied. Differences among positions were also found concerning body composition; goalkeepers showed the highest body fat percentage $(9.4 \pm 1.4 \%)$. Mean somatotype was also different among positions; goalkeepers and forwards presented a balanced mesomorph somatotype while defenders and midfielders showed an ecto-mesomorph one.

The differences in morphological characteristics according to the team position were notice only in goalkeepers, especially regarding their weight, abdominal and supraespinale skinfolds and the percentage of fat tissue.

\section{More Information}

*Address for Correspondence: MM Cavia, Nutrición y Bromatología, Facultad de Ciencias, Universidad de Burgos, E-09001 Burgos, Spain, Tel: +34 947259 003; Email: mmcavia@ubu.es

Submitted: 26 September 2019

Approved: 31 October 2019

Published: 01 November 2019

How to cite this article: Cavia MM, Moreno A, Fernández-Trabanco B, Carrillo C, AlonsoTorre SR. Anthropometric characteristics and somatotype of professional soccer players by position. J Sports Med Ther. 2019; 4: 073-080.

DOI: dx.doi.org/10.29328/journal.jsmt.1001047

Copyright: (C) 2019 Cavia MM, et al. This is an open access article distributed under the Creative Commons Attribution License, which permits unrestricted use, distribution, and reproduction in any medium, provided the original work is properly cited

Keywords: Anthropometry; Body fat; Skinfolds; Soccer; Somatotype

Check for updates

\section{Introduction}

Football is the most popular and played sport in the world and during the last decades a number of research has focused on studying the factors that influence the performance of a player [1-4].

Some studies conclude that there is a close relation between the anthropometric and the physiologic characteristics of the player and its ability to play football at a certain level $[1,5,6]$; such characteristics are decisive for an optimal physical level and therefore a good level in the game $[4,7,8]$.

These researches aim to find the ideal football player: how his body composition, somatotype, training, diet or rest should be and what qualities and anatomical characteristics should the player have according to his position $[1,3,4]$. Weight, height and skinfolds are the anthropometric measurements most commonly studied. However, it is necessary to explore better the anthropometric characteristics of the players including diameters and body circumferences.

Body composition is one of the most influencing factors concerning sport performance, since the excess of adipose tissue acts as a dead weight in activities such a running or jumping [9]. Many studies determine body composition through the skinfolds measurement $[2,4,6,7,10,11]$. However, it is difficult to compare the results since different equations are used among them $[1,3,4,10]$. Therefore, it is important to 
apply the different available equations in the same population in order to elucidate which are the most convenient to determine body composition in football players.

Somatotype is another important feature to take into account. Football players usually show a mesomorph trend; however, different trends according to playing positions could be observed. Several authors indicate that goalkeepers usually accumulate higher fat amounts [11], thus, somatotype components could be an important factor to locate a player in the field.

Therefore, the aim of this study was to identify the physical characteristics, body composition and somatotype of professional soccer players and to verify differences according to their playing positions. In addition, different equations to determine body composition were applied in order to ascertain which gave similar results for this population.

\section{Materials and Methods}

A cross-sectional descriptive study has been carried out. The studied population consisted of 57 male players, aged between 19 and 35, belonging to a soccer team that participated in the Spanish Football League One. The players were grouped according to their positions as goalkeepers (n $=5)$, defenders $(n=15)$, midfielders $(n=26)$ and forwards $(\mathrm{n}=11)$. Participants provided written informed consent. The study was approved by Bioethics Commission of the University of Burgos.

Anthropometric measurements were performed during the first round of the league competition, after overnight fasting before breakfast and before the training. These measurements were performed according to procedures proposed by International Society for the Advancement of Kinanthropometry [12]. All measurements were taken from the right side of the body by the same evaluator certified by ISAK.

To describe the physical characteristics, body composition and somatotype of the soccer players, different measurements were taken: height and body weight, four bone breadths, eleven girths and ten skinfolds. Height was measured using a portable stadiometer (SECA 213) with accuracy of $0.1 \mathrm{~cm}$, body weight (BW) using an electronic balance scale (Tanita TBF 401A, Japan) with accuracy of $0.1 \mathrm{~kg}$, breadths were measured using a bicondylar calliper (Holtain Ltd, Crymych, U.K.) with accuracy of $0.1 \mathrm{~cm}$, girths were measured using a non-elastic tape (Cescorf, Mexico) with accuracy $0.1 \mathrm{~cm}$ and skinfold measurements were taken using a skinfold calliper (Holtain Ltd, Crymych, U.K.) with accuracy of 0.2 $\mathrm{mm}$. In addition Bioelectrical Impedance Analysis (BIA) was performed using a tetra-polar system BioScan Spectrum ${ }^{\circledR}$ at a frequency at $50 \mathrm{KHz}$.

Body mass index (BMI) was calculated as weight (in kilograms) $/$ height $^{2}$ (in meters). Body density was calculated by equations of Durnin and Womersley [13], one of them using the tricipital skinfold (1SF) and another using four skinfolds (4SF); by equations of Jackson and Pollock [14], one of them using three skinfolds (3SF) and another using seven skinfolds (7SF); and equation of Whiters and colleagues [15] using four skinfolds. Then, body fat was determinated by Siri equation [16] for each of the densities previously calculated. Besides that, body fat was determined by equations of Carter [17], Cossio-Bolaños [18] and Faulkner [19] and by Bioelectrical Impedance Analysis (BIA) through equations of Heyward and Stolarczyk [20], Segal [21] and Deurenberg [22].

The three somatotype components were calculated according to the Heath-Carter anthropometric somatotyping method [23].

Descriptive statistics were used, with data presented as the mean and standard deviation, to characterize the sample according to the playing position. The normality of the data was analyzed using the Kolmogorov Smirnov test. Analysis of variance (ANOVA) and the post hoc LSD test were used to compare anthropometric variables according to the playing position. The Kruskal-Wallis test was used for no normal variables. The significance level was set at $5 \%$. Statgraphics Centurion XVI v. 16.2.04 was used to statistical analysis.

\section{Results}

The global anthropometric characteristics of the participants and according to the playing position are presented in table 1 . Differences $(p<0.05)$ were observed for body weight and BMI. Goalkeepers were heavier than midfielders and they had a higher BMI than midfielders and defenders.

In addition, differences $(p<0.05)$ in the anthropometric measurements were observed. Herein ankle breadth measurements (midfielders lower values than other positions), girths of arm relaxed, forearm and calf (in all four measurements goalkeepers had higher values than midfielders); and ankle girth (forwards higher values than midfielders). No differences according to position were observed in skinfolds, except in supraespinal and abdominal, being goalkeepers higher than other positions.

Body fat (\%) has been determined by different equations. Figure 1 shows mean values of each equation for all players. There are no significant differences in body fat determined by 3SF, 7SF, Carter, Heyward-Stolarczyk and Withers equations. From these values, the mean body fat for each player was calculated and differences between playing positions were analysed (Table 2). Goalkeepers had a higher body fat than others positions, although no significant differences with defenders were observed.

Table 3 shows the mean values for each somatotype component and the classification somatotype. The mean somatotype was ecto-mesomorph. The mesomorph is the 
Table 1: Anthropometric characteristics of soccer players by position. Average values + SD and range are displayed. Different letters show significant differences between positions $(p<0.05)$. For each parameter.

\begin{tabular}{|c|c|c|c|c|c|c|c|c|c|c|c|}
\hline & \multicolumn{2}{|c|}{ GLOBAL $(n=57)$} & \multicolumn{2}{|c|}{ GOALKEEPERS $(n=5)$} & \multicolumn{2}{|c|}{ DEFENDERS $(n=15)$} & \multicolumn{2}{|c|}{ MIDFIELDERS $(n=26)$} & \multicolumn{2}{|c|}{ FORWARDS $(n=11)$} & \multirow{2}{*}{$\begin{array}{l}\boldsymbol{p} \text { value } \\
0.5858\end{array}$} \\
\hline Age (years) & $25.8 \pm 3.9$ & $(19.0-35.0)$ & $24.8 \pm 6.3$ & $(19.0-33.0)$ & $26.9 \pm 4.3$ & $(19.0-35.0)$ & $25.6 \pm 2.5$ & $(19.0-29.0)$ & $25.0 \pm 4.8$ & $(19.0-34.0)$ & \\
\hline Body Weight (kg) & $74.3 \pm 6.5$ & $(52.5-88.1)$ & $80.2 \pm 3.2^{b}$ & $(76.0-84.9)$ & $74.9 \pm 5.5^{\mathrm{a} . \mathrm{b}}$ & $(62.4-86.7)$ & $72.0 \pm 7.2^{\mathrm{a}}$ & $(52.5-81.3)$ & $75.9 \pm 5.2^{a . b}$ & $(69.7-88.1)$ & 0.0395 \\
\hline Body Height (cm) & $179.8 \pm 6.3$ & $(165.0-193.0)$ & $181.8 \pm 3.2$ & $(177.0-185.8)$ & $181.5 \pm 5.5$ & $(171.0-192.0)$ & $178.3 \pm 6.9$ & $(165.0-181.5)$ & $180.5 \pm 7.0$ & $(168.0-193.0)$ & 0.3646 \\
\hline $\mathrm{BMI}\left(\mathrm{kg} / \mathrm{m}^{2}\right)$ & $22.9 \pm 1.2$ & $(19.3-25.6)$ & $24.3 \pm 1.3^{b}$ & $(22.9-25.6)$ & $22.7 \pm 0.8^{a}$ & $(21.3-24.3)$ & $22.6 \pm 1.2^{\mathrm{a}}$ & $(19.3-25.0)$ & $23.4 \pm 1.3^{a . b}$ & $(21.5-25.2)$ & 0.0142 \\
\hline \multicolumn{12}{|c|}{ BREADTH (cm) } \\
\hline Humeral & $7.0 \pm 0.4$ & $(6.3-8.0)$ & $7.1 \pm 0.3$ & $(6.7-7.4)$ & $7.1 \pm 0.4$ & $(6.5-8.0)$ & $6.8 \pm 0.3$ & $(6.3-7.4)$ & $7.0 \pm 0.4$ & $(6.3-7.9)$ & 0.2118 \\
\hline Wrist & $5.6 \pm 0.4$ & $(4.7-6.7)$ & $5.7 \pm 0.4$ & $(5.3-6.2)$ & $5.7 \pm 0.5$ & $(5.0-6.7)$ & $5.5 \pm 0.4$ & $(4.7-6.5)$ & $5.7 \pm 0.4$ & $(5.3-6.4)$ & 0.4474 \\
\hline Femoral & $9.2 \pm 0.6$ & $(8.0-10.3)$ & $9.4 \pm 0.6$ & $(8.5-10.3)$ & $9.4 \pm 0.5$ & $(8.8-10.3)$ & $9.2 \pm 0.6$ & $(8.0-10.1)$ & $9.0 \pm 0.6$ & $(8.1-10.0)$ & 0.1754 \\
\hline Ankle & $7.4 \pm 0.4$ & $(6.3-8.2)$ & $7.7 \pm 0.2^{b}$ & $(7.5-7.9)$ & $7.5 \pm 0.4^{b}$ & $(6.9-8.2)$ & $7.3 \pm 0.4^{\mathrm{a}}$ & $(6.3-7.9)$ & $7.6 \pm 0.4^{b}$ & $(7.0-8.1)$ & 0.0227 \\
\hline \multicolumn{12}{|c|}{$\operatorname{GIRTH}(\mathrm{cm})$} \\
\hline Neck & $38.3 \pm 1.6$ & $(35.5-42.5)$ & $39.2 \pm 2.0$ & $(37.6-42.5)$ & $38.1 \pm 1.4$ & $(36.3-41.1)$ & $38.0 \pm 1.7$ & $(35.5-42.0)$ & $39.1 \pm 1.6$ & $(36.8-41.8)$ & 0.1591 \\
\hline Upper arm relaxed & $30.5 \pm 2.1$ & $(27.0-39.5)$ & $32.7 \pm 1.6^{b}$ & $(30.6-34.2)$ & $30.8 \pm 1.3^{b}$ & $(29.0-34.2)$ & $29.8 \pm 1.7^{\mathrm{a}}$ & $(27.0-33.0)$ & $31.1 \pm 3.1^{\text {a.b }}$ & $(28.8-39.5)$ & 0.0160 \\
\hline $\begin{array}{l}\text { Upper arm flexed and } \\
\text { tensed }\end{array}$ & $32.4 \pm 2.0$ & $(27.3-36.5)$ & $33.8 \pm 1.9$ & $(31.2-35.7)$ & $32.9 \pm 1.7$ & $(30.6-36.5)$ & $31.7 \pm 2.0$ & $(27.3-35.0)$ & $32.7 \pm 1.7$ & $(30.8-36.0)$ & 0.0534 \\
\hline Wrist & $16.8 \pm 0.8$ & $(14.8-18.8)$ & $17.4 \pm 0.6$ & $(16.8-18.1)$ & $16.8 \pm 0.8$ & $(15.9-18.0)$ & $16.6 \pm 0.8$ & $(14.8-18.0)$ & $17.0 \pm 0.7$ & $(15.7-18.8)$ & 0.1735 \\
\hline Forearm & $27.2 \pm 1.2$ & $(24.1-29.8)$ & $28.3 \pm 1.0^{\mathrm{b}}$ & $(26.9-29.7)$ & $27.6 \pm 1.2^{\mathrm{b}}$ & $(25.4-29.8)$ & $26.5 \pm 1.0^{\mathrm{a}}$ & $(24.1-29.0)$ & $27.6 \pm 1.1^{b}$ & $(25.8-28.8)$ & 0.0011 \\
\hline Waist & $80.8 \pm 3.9$ & $(72.3-93.5)$ & $84.0 \pm 5.5$ & $(79.7-93.5)$ & $80.9 \pm 3.8$ & $(74.6-85.8)$ & $79.8 \pm 3.6$ & $(72.3-86.5)$ & $81.6 \pm 3.4$ & $(75.7-86.5)$ & 0.1286 \\
\hline Iliac crest & $83.9 \pm 5.5$ & $(72.6-97.0)$ & $86.7 \pm 3.9$ & $(82.8-93.3)$ & $83.9 \pm 5.1$ & $(75.9-96.0)$ & $83.1 \pm 5.8$ & $(72.6-94.9)$ & $85.1 \pm 6.6$ & $(77.2$ - 97.0) & 0.7602 \\
\hline Gluteal (hip) & $96.1 \pm 4.0$ & $(84.5-106.5)$ & $97.8 \pm 1.1$ & $(96.7-99.0)$ & $95.3 \pm 4.2$ & $(87.1-103.0)$ & $95.7 \pm 4.3$ & $(84.5-104.4)$ & $97.6 \pm 3.9$ & $(92.5-106.5)$ & 0.3368 \\
\hline Mid-thigh & $53.7 \pm 2.6$ & $(48.7-60.8)$ & $54.1 \pm 3.7$ & $(48.7-57.5)$ & $53.3 \pm 2.9$ & $(49.0-58.5)$ & $53.3 \pm 2.6$ & $(49.0-60.8)$ & $54.7 \pm 2.1$ & $(52.0-57.5)$ & 0.4750 \\
\hline Calf & $37.9 \pm 1.6$ & $(34.0-41.5)$ & $39.1 \pm 1.5^{b}$ & $(37.5$ - 41.5) & $37.6 \pm 1.4^{a . b}$ & $(35.1$ - 40.2) & $37.5 \pm 1.7^{\mathrm{a}}$ & $(34.0-40.8)$ & $38.8 \pm 1.2^{\mathrm{b}}$ & $(37.1-41.3)$ & 0.0385 \\
\hline Ankle & $23.2 \pm 1.5$ & $(19.8-29.0)$ & $23.3 \pm 0.6^{a . b}$ & $(22.4-24.0)$ & $23.1 \pm 1.1^{\mathrm{a}}$ & $(21.1-25.0)$ & $22.7 \pm 1.3^{\mathrm{a}}$ & $(19.8-25.0)$ & $24.4 \pm 1.9^{b}$ & $(22.3-29.0)$ & 0.0097 \\
\hline \multicolumn{12}{|c|}{ SKINFOLDS (mm) } \\
\hline Biceps & $3.8 \pm 0.8$ & $(2.5-5.9)$ & $4.4 \pm 1.1$ & $(3.2-5.9)$ & $3.8 \pm 0.8$ & $(2.5-5.5)$ & $3.7 \pm 0.7$ & $(2.7-5.1)$ & $3.7 \pm 0.8$ & $(2.5-4.8)$ & 0.3503 \\
\hline Triceps & $7.4 \pm 2.3$ & $(3.2-15.8)$ & $8.9 \pm 1.7$ & $(6.3-10.5)$ & $7.3 \pm 2.0$ & $(3.2-11.3)$ & $7.4 \pm 2.6$ & $(4.3-15.8)$ & $6.7 \pm 1.8$ & $(5.0-10.9)$ & 0.3502 \\
\hline Subscapular & $9.2 \pm 1.7$ & $(6.4-13.1)$ & $10.5 \pm 1.8$ & $(7.8-12.8)$ & $9.1 \pm 1.4$ & $(6.7-11.1)$ & $8.8 \pm 1.8$ & $(6.4-13.1)$ & $9.5 \pm 2.0$ & $(6.6-12.7)$ & 0.2306 \\
\hline Pectoral & $5.9 \pm 1.5$ & $(4.0-11.9)$ & $7.6 \pm 2.8$ & $(4 .-11.9)$ & $6.0 \pm 1.4$ & $(4.3-8.7)$ & $5.7 \pm 0.9$ & $(4.0-7.2)$ & $5.7 \pm 1.5$ & $(4.0-9.2)$ & 0.0576 \\
\hline Axillary & $6.9 \pm 1.9$ & $(4.5-11.3)$ & $7.8 \pm 2.9$ & $(4.9-10.9)$ & $7.0 \pm 1.7$ & $(4.5-10.2)$ & $6.8 \pm 1.8$ & $(4.9-10.5)$ & $6.9 \pm 2.1$ & $(4.7-11.3)$ & 0.7169 \\
\hline Suprailiac & $10.0 \pm 4.2$ & $(4.7-22.5)$ & $13.9 \pm 5.0$ & $(10.1-22.5)$ & $10.1 \pm 4.8$ & $(4.7-19.4)$ & $9.1 \pm 3.2$ & $(4.9-16.7)$ & $10.2 \pm 4.7$ & $(5.3-20.0)$ & 0.1407 \\
\hline Supraespinale & $7.4 \pm 2.3$ & $(3.9-17.0$ & $10.5 \pm 3.8^{b}$ & $(7.4-17.0)$ & $7.3 \pm 1.8^{\mathrm{a}}$ & $(4.5-10.6)$ & $7.0 \pm 2.0^{\mathrm{a}}$ & $(3.9-11.5)$ & $6.8 \pm 1.9^{\mathrm{a}}$ & $(4.9-10.2)$ & 0.0091 \\
\hline Abdominal & $11.0 \pm 3.3$ & $(5.8-19.9)$ & $15.6 \pm 3.5^{b}$ & $(11.3-19.9)$ & $11.2 \pm 2.7^{a}$ & $(6.4-15.4)$ & $10.4 \pm 3.2^{\mathrm{a}}$ & $(5.8-16.5)$ & $10.4 \pm 3.1^{\mathrm{a}}$ & $(7.2-15.0)$ & 0.0095 \\
\hline Front thigh & $9.3 \pm 3.0$ & $(4.7-18.6)$ & $11.4 \pm 3.3$ & $(7.1-15.7)$ & $10.2 \pm 3.7$ & $(6.2-18.6)$ & $8.4 \pm 2.1$ & $(4.7-13.8)$ & $9.2 \pm 3.4$ & $(6.4-18.0)$ & 0.1218 \\
\hline Medial calf & $5.6 \pm 1.9$ & $(3.2-13.9)$ & $7.2 \pm 2.4$ & $(4.8-10.5)$ & $6.0 \pm 2.5$ & $(3.3-13.9)$ & $5.0 \pm 1.2$ & $(3.2-7.7)$ & $5.4 \pm 1.8$ & $(3.8-9.9)$ & 0.0830 \\
\hline
\end{tabular}

Table 2: Body fat (\%) of players by position. Different letters show significant differences $(p<0.05)$ by position (LSD test).

\begin{tabular}{|c|c|c|}
\hline \multirow{2}{*}{ Position } & \multicolumn{2}{|c|}{ Body Fat (\%) } \\
\hline Goalkeepers & Mean \pm SD & Range \\
\hline Defenders & $9.4 \pm 1.4^{\mathrm{b}}$ & $7.7-11.5$ \\
\hline Midfielders & $8.0 \pm 1.6^{\mathrm{a}, \mathrm{b}}$ & $6.1-10.8$ \\
\hline Forwards & $7.4 \pm 1.3^{\mathrm{a}}$ & $5.0-9.6$ \\
\hline Global & $7.7 \pm 1.4^{\mathrm{a}}$ & $5.9-10.5$ \\
\hline & $7.8 \pm 1.5$ & $5.0-11.5$ \\
\hline
\end{tabular}

Table 3: Somatotype of players by position. Different letters show significant differences $(p<0.05)$ by position (LSD test).

\begin{tabular}{|c|c|c|c|c|c|c|c|c|}
\hline \multirow{2}{*}{ Position } & \multicolumn{2}{|c|}{ Endomorphy } & \multicolumn{2}{c|}{ Mesomorphy } & \multicolumn{2}{c|}{ Ectomorphy } & Soma to type \\
\hline Goalkeepers & $2.8 \pm 0.6^{\mathrm{b}}$ & $2.0-3.6$ & $4.8 \pm 1.3^{\mathrm{a}}$ & $3.5-6.2$ & $2.3 \pm 0.7^{\mathrm{a}}$ & $1.5-3.1$ & $\begin{array}{c}\text { Balanced } \\
\text { Mesomorph }\end{array}$ \\
\hline Defenders & $2.2 \pm 0.4^{\mathrm{a}}$ & $1.5-2.9$ & $4.5 \pm 0.5^{\mathrm{a}}$ & $3.4-5.2$ & $2.9 \pm 0.4^{\mathrm{b}}$ & $2.1-3.7$ & $\begin{array}{c}\text { Ecto- } \\
\text { mesomorph }\end{array}$ \\
\hline Midfielders & $2.2 \pm 0.6^{\mathrm{a}}$ & $1.5-3.4$ & $4.3 \pm 0.9^{\mathrm{a}}$ & $2.2-6.2$ & $2.8 \pm 0.6^{\mathrm{a}, \mathrm{b}}$ & $1.7-4.5$ & $\begin{array}{c}\text { Ecto- } \\
\text { mesomorph }\end{array}$ \\
\hline Forwards & $2.1 \pm 0.4^{\mathrm{a}}$ & $1.3-2.7$ & $4.5 \pm 0.9^{\mathrm{a}}$ & $2.8-5.8$ & $2.6 \pm 0.9^{\mathrm{ab}} \mathrm{b}$ & $1.3-3.8$ & $\begin{array}{c}\text { Balanced } \\
\text { Mesomorph }\end{array}$ \\
\hline Global & $2.2 \pm 0.5$ & $1.3-3.6$ & $4.4 \pm 0.8$ & $2.2-6.2$ & $2.8 \pm 0.6$ & $1.3-4.5$ & $\begin{array}{c}\text { Ecto- } \\
\text { mesomorph }\end{array}$ \\
\hline Reference & 2.2 & & 5.1 & & 1.9 & $\begin{array}{c}\text { Balanced } \\
\text { Mesomorph }\end{array}$ \\
\hline
\end{tabular}

Box-and-Whisker Plot

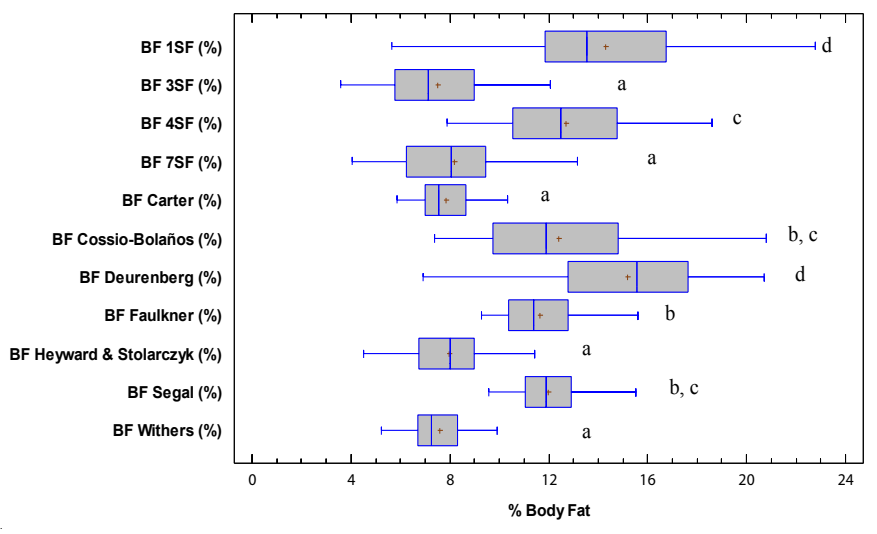

Figure 1: Body fat (\%) by different equations. Different letters show significant differences $(p=0,000)$ in body fat (\% BF) between different equations (LSD test). 1SF: body density by equation of Durnin and Womersley (1974) using the tricipital skinfold; 3SF: equation of Jackson and Pollock (1978) using three skinfolds; 4SF: body density by equation of Durnin and Womersley (1974) using four skinfolds; 7SF: equation of Jackson and Pollock (1978) using seven skinfolds. 
most important component in all positions. Goalkeepers had a heavier first component of somatotype than others positions $(p<0.05)$.

The percentage of soccer players which fall under each somatotype categories according to their position is showed in table 4. Most of the players showed a somatotype ecto-mesomorph followed by balanced mesomorph. The component endomorph is the less representative.

To ease the interpretation of the somatotype results, a somatochart was performed for each individual position (Figure 2). Defenders are all located in the ecto-mesomorph quadrant, while the other positions showed a higher dispersion.

Table 4: The percentage of soccer players which fall under each of major somatotype categories by position.

\begin{tabular}{|c|c|c|c|c|c|}
\hline $\begin{array}{c}\text { \% Soccer players } \\
\text { Balanced Endomorph }\end{array}$ & Goalkeepers & Defenders & Midfielders & Forwards & Total \\
\hline $\begin{array}{c}\text { Meso-Endomorph } \\
\begin{array}{c}\text { Mesomorph } \\
\text { Endomorph }\end{array}\end{array}$ & & & & & \\
\hline $\begin{array}{c}\text { Endo-Mesomorph } \\
\text { Balanced Mesomorph }\end{array}$ & 40 & & 4 & 18 & 9 \\
\hline $\begin{array}{c}\text { Ecto-Mesomorph } \\
\text { Mesomorph } \\
\text { Ectomorph }\end{array}$ & 20 & 33 & 23 & 27 & 26 \\
\hline Meso-Ectomorph & 20 & 47 & 42 & 27 & 37 \\
\hline $\begin{array}{c}\text { Balanced Ectomorph } \\
\text { Endo-Estomorph }\end{array}$ & & & 4 & 9 & 14 \\
\hline Endomorph Ectomorph & & & & & 4 \\
\hline Ecto-Endomorph & & & & & \\
\hline Central & 20 & & 12 & 9 & 9 \\
\hline
\end{tabular}
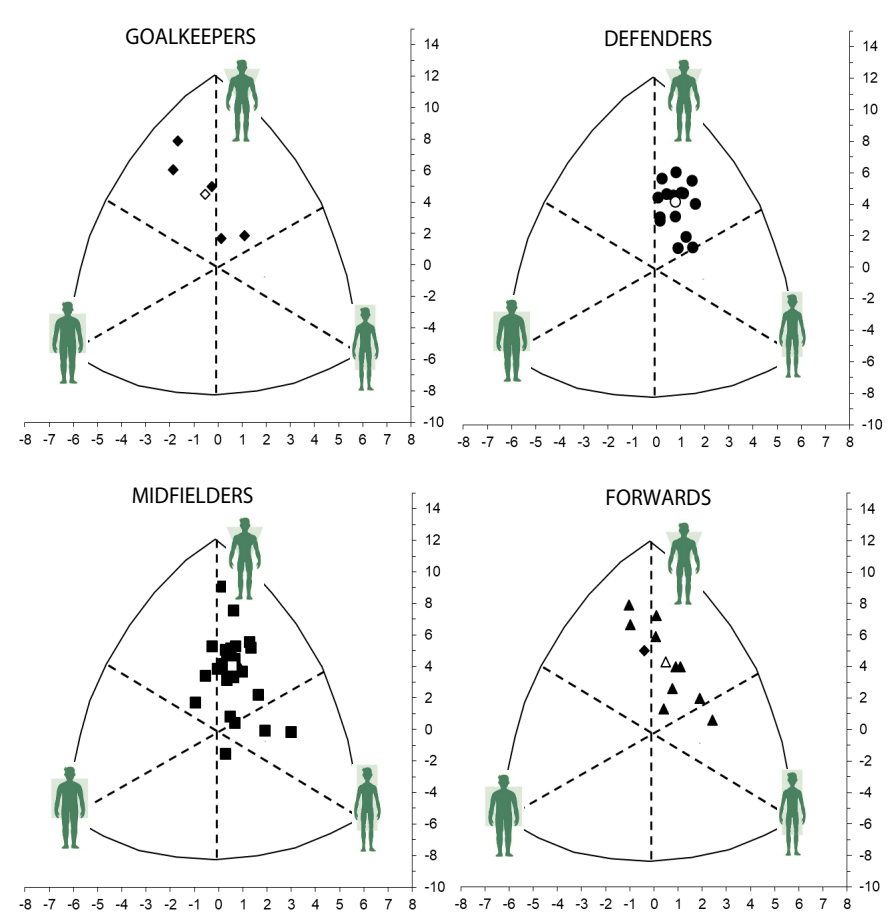

Figure 2: Somatotype distribution (somatochart) of soccer players by position. Black diamond: goalkeepers; black circle: defenders; black square: midfielders; black triangle: forwards. White symbols: average value by position

\section{Discussion}

The average weight and height data obtained in our study are in accordance with previous reports about professional soccer players [3,4,24-26,29-31]. Herrero [32] show similar weights for players of the same category as those of our sample, although higher values were observed for upper categories.

Concerning weight values, significant differences among positions were observed, being goalkeepers and defenders those showing the highest body mass. Similar results were observed in previous reports $[3,25,28,29,32]$.

Taking into account the playing positions, no significant differences in height were observed, although goalkeepers and defenders showed higher height values than midfielders and forwards, which is in line with other authors [1,3,5,25,28,29]. However, the research group of Cossio-Bolaños [33], observed that forwards presented higher height values than defenders.

The goalkeepers must compete with other players for the ball in the air, so players with greater height and greater weight have an advantage. This fact also makes it easier for them to cover the entire goal area [6].

Average BMI values are in line with those obtained by Pau, et al. [34], but lower than those reported by Hazir, [28].

Significant differences among the BMI of the players, according to their position, were observed in our study, with goalkeepers showing the highest value. In contrast, Hazir [28], did not find differences among positions.

There is a lack of studies including as many anthropometric parameters as those presented in this report. Mean average humeral and femoral breadth values obtained in our study were in line with those reported by Hazir [28] and Brocherie, et al. [4]. The four breadths measured in the present research were similar to those observed by Herrero [32].

When facing the analysis of such anthropometric measurements by playing positions, significant differences were observed for ankle breadth, where midfielders showed significantly lower values. Herrero [32], in a study about players of different categories, did not find differences for the body breadths analyzed according to the playing positions. Our results suggest that bone complexion is similar among soccer players, independently of their playing position.

There is a lack of references with regards to body girths. Similar values for upper arm flexed and tensed, mid-thigh and calf are reported by Hazir [28] and Brocherie, et al. [4]. These latest authors showed lower upper arm relaxed, forearm and waist values, although it is important to highlight that such soccers played for the National team of Qatar and those evaluated in the present study belong to lower categories. Our results showed higher values than those observed by Herrero [32] for neck, upper arm flexed and iliac crest. 
With regards to the playing position, similar values were observed among defences, midfielders and forwards; goalkeepers showed higher values in almost all the girths values analysed, although no significant differences were observed in every case. It is important to highlight the low values found among midfielders regarding upper arm relaxed, forearm and calf. These results are in line with those reported by Herrero [32].

Although the average skinfold values obtained in our sample are similar to those published in several studies, higher values than those reported for Spanish players [35] and for players from Qatar [4], were observed for suprailiac and abdominal skinfolds; also, triceps skinfold values were higher than those reported by Herrero [32]. In a study focused on players from Peru [26], found higher values for subscapular, suprailiac, abdominal and leg skinfolds and lower values for front thigh skinfold. Comparing with the results from CossioBolaños, et al. [33], Peruvian players showed higher values in subscapular, suprailiac and abdominal skinfolds.

Our results showed significant differences in supraespinal and abdominal skinfolds, according to the playing possition, being goalkeepers those players with the highest values. No significant differences were observed among playing positions for the other skinfolds measured, although goalkeepers always presented the highest values. Similar findings were observed in other studies [33]. Herrero [32], within Spanish players, found that goalkeepers showed lower values just in triceps and supraespinal skinfold.

Body fat is a compound that decreases the performance since it acts as a dead weight in activities where the body mass is loaded against the gravity [36]. Results from literature vary from $6-15 \%$ of body fat $[1,31,37]$. Such differences could be related to the different methods used, which makes difficult the comparison.

Different equations were used to determine the percentage of body fat, and no significant differences among 3SF, 7SF, Withers, Carter and Heyward and Stolarczyk equations were observed. Higher values were obtained when applying the other equations (1SF, 4SF, Faulkner, Deurenberg and Segal). Some authors consider that those equations that do not include lower body skinfolds could give failed data, improving the results when front thigh and medial calf skinfolds are included $[38,39]$, as occurs in the equation of Carter. Therefore, in this study 3SF, 7SF, Withers, Carter and Heyward \& Stolarczyk equations have been selected to obtain an average body fat value and then calculate the body composition of the players.

The mean value obtained from these 5 equations (Table 2 ) is used to evaluate the nutritional status of the players. Similar average values were observed by other authors $[7,24,40]$, who used equations of Yushaz, Carter and JacksonPollock, respectively. However, higher values were reported by Herrero, et al. [7] and Casajús and Aragonés [24] and when using the equation of Faulkner; by Sutton, et al. [3], when taking the equation of Withers; by Cossio-Bolaños and Santi Maria [41] with the equation of Cossio-Bolaños, et al. [18] and by Matkovic, et al. [5] by electrical bioimpedance. This is in line with our results, since the equations of Faulkner and Cossio-Bolaños also gave higher values than those of Carter, Jackson-Pollock y Withers.

Facing the study of body fat based on the playing position, goalkeepers followed by defenders presented higher body fat values than players from the other positions. Similar results were obtained in Greek [31], Spanish [32] and Brazilian [37] professional soccer players. Matkovic, et al. [5], in elite Croatian soccer players, also found higher body fat percentages in goalkeepers; however, defenders showed the lowest values. Hacken and White [25], in players from the Premiership football club in England, also observed that the goalkeepers were those players with higher body fat values and higher variability on such parameter, followed by the forwards. However, Cossio-Bolaños and Santi Maria [41] observed that midfielders had the higher body fat percentage followed by goalkeepers, being the forwards those who showed the lowest values within the Peruvian players analysed.

These results are in line with those reported in literature. Previous research has shown that defenders and goalkeepers presented high values of body fat since they are submitted to a lower metabolic overload, both during the training sessions and during the games [31,37].

When using the percentage of body fat to determine the nutritional status of the players, $55.8 \%$ of the sample had low values according to Gallagher, et al. [42] for general population. The rest show healthy values. Similar results are obtained according to the classification given by Cossio-Bolaños, et al. [36]; $28.1 \%$ of the population is on an ideal situation, $19.3 \%$ under thinness and $52.6 \%$ under risk because of a low fat value.

According to the playing position, forwards show the higher percentage of players with low body fat values (54.5\%), followed by midfielders (53.8\%), defenders $(53.3 \%)$ and goalkeepers (20.0\%), according to Gallagher, et al. [42]. According to the cut points given by Cossio-Bolaños, et al. [36], defenders showed the highest number of players with a low fat percentage $(73.3 \%)$, followed by forwards $(72.2 \%)$, midfielders (69.2\%) and goalkeepers (20\%). Surprisingly, more players with low fat values are found when using the cut points related to athletes in comparison with the cut points established for general population. This could be due to the fact that in the present study the mean body fat percentage has been obtained from different equations but that from CossioBolaños, which gives higher results, is not included. Therefore, in order to perform a correct nutritional status assessment, it is important to fix the method used to determine the body composition in athletes and establish cut points specifics to the method applied. 
The average somatotype of the players was balanced mesomorph. Other authors have also reported a balanced mesomorph somatotype $[27,28,31,32,43]$. Some studies have found a mean endo-mesomorph somatotype [24,44]. Brocherie, et al. [4] observed a mean ecto-mesomorph somatotype. It is important to highlight that the endomorphy and mesomorphy components obtained in our study are lower than those reported in the literature, while the ectomorphy component was higher. It could be suggested that the players evaluated have a lower skeletal muscle mass and a higher predominance of linear and weak shapes [45]. These results are in line with the low body fat percentages found in our players in comparison to those previously reported in literature.

The average somatotype of goalkeepers is balanced mesomorph, with the endomorphy component slightly higher than the ectomorphy, according to their higher body fat percentage. Similar findings were observed for Spanish players [32], in players from the Turkist League [28] and for semiprofesional players [43]. In contrast, Henríquez-Olguín, et al. [29] found that the ectomorphy component is more important than the endomorphy in players from Chile.

The defenses showed a mean ecto-mesomorph somatotype. In contrast, other authors have reported a balanced mesomorph somatotype for the defenders [28,29]. Almagia, et al. [44] found an endo-mesomorph somatotype. In most of the studies, the endomorphy component is higher than the ectomorphy, which is in disagreement with our results.

Our results show that midfielders presented a mean ectomesomorph somatotype. However, Hazir, [28], HenríquezOlguín, et al. [29] and Almagia, et al. [44] found a balanced mesomorph or endo-mesomorph for such playing position, with a lower ectomorphy component than ours.

The forwards evaluated in our study showed a mean balanced mesomorph somatotype, with the ectomorphy component higher than the endomorphy. These results are in agreement with those reported by Henríquez-Olguín, et al. [29]. In contrast, Hazir, [28] and Almagia, et al. [44] observed that the endomorphy component was higher than the ectomorphy. The differences observed among the somatotype components of football players are influenced by their activity within the field and during the training sessions [46].

According to the somatochart, a poor homogeneous distribution of the players is observed, even by playing positions. In contrast, Almagia, et al. [44] did not find differences by playing positions, with all the players located in the upper left region of the somatochart, with an endomesomorph somatotype.

\section{Conclusion}

The differences in morphological characteristics according to the team position were notice only in goalkeepers, especially regarding their weight, abdominal and supraespinale skinfolds and the percentage of fat tissue. These characteristics showed a low body fat percentage with a trend towards the muscle development based on the mesomorfic component in the somatotype.

To determine the percentage of body fat by anthropometry, the equations used must be chosen well since not all yield similar results.

It is important to develop more studies concerning the different equations available to determine body fat, since they give different results; in addition, specific cut points for each equation should be established in order to assess the nutritional status of the athletes in a proper way.

This study has as limitations the small number of players evaluated, members of the same soccer team.

In order to better study the differences by game position and assess which equations for determining body fat are more suitable for this group, it would be necessary to have a greater number of participants and employ a body fat measurement technique that can serve of reference, as for example DXA.

\section{Aknowledgements}

The study was designed by MMC and SRAT; data were collected by AM and BFT, data were analysed by MMC, SRAT, AM, CC and BFT, data interpretation and manuscript preparation were undertaken by MMC, SRAT, AM, CC and BFT. All authors approved the final version of the paper.

We would like to thank to Manuel Sillero Quintana for his contribution in the analysis of the somatotypes and to the players involved in the present study.

\section{Funding}

This work was supported by the Caja Círculo and Caja de Burgos-Fundación Bancaria with grant number: A11N05.

\section{References}

1. Reilly T, Bangsbo J, Franks A. Anthropometric and physiological predispositions for elite soccer. J Sports Sci. 2000; 18: 669-683. PubMed: https://www.ncbi.nlm.nih.gov/pubmed/11043893

2. Arroyo M, González-de-Suso JM, Sánchez C, Ansotegui L, Rocandio AM Body Image and Body Composition: Comparisons of Young Male Elite Soccer Players and Controls. Int J Sport Nutr Exe. 2008; 18: 628-638. PubMed: https://www.ncbi.nlm.nih.gov/pubmed/19164832

3. Sutton L, Scott M, Wallace J, Reilly T. Body composition of English premier League soccer players: influence of playing position, international status and ethnicity. J Sports Sci. 2009; 27: 1019-1026. PubMed: https://www.ncbi.nlm.nih.gov/pubmed/19847685

4. Brocherie F, Girard O, Forchino F, Al Haddad H and Dos Santos GA et al. Relationships between anthropometric measures and athletic performance, with special reference to repeated-sprint ability, in the Qatar national soccer team. J. Sports Sci. 2014; 32: 1243-1254.

PubMed: https://www.ncbi.nlm.nih.gov/pubmed/24742185 
5. Matkovic BR, Misigoj-Durakovic M, Matkovic B, Jankovic S and Ruzic $\mathrm{L}$, et al. Morphological differences of elite Croatian soccer players according to the team position. Coll Antropol. 2003; 7: S167-S174. PubMed: https://www.ncbi.nlm.nih.gov/pubmed/12955906

6. Arnason A, Sigurdsson A, Gudmundsson I, Holme L and Engebretsen $\mathrm{L}$, et al. Physical fitness, injuries and team performance in soccer. Med Sci Sports Exerc. 2004; 36: 278-285.

PubMed: https://www.ncbi.nlm.nih.gov/pubmed/14767251

7. Herrero A, Cabañas MD, Maestre I. Morfotipo del futbolista profesional de la Comunidad Autónoma de Madrid. Composición corporal. [Morphotype of the professional soccer player of the Madrid Autonomous Community. Body composition]. Biomecánica. 2004; 12: 72-77.

8. Lukaski HC. Body composition: health and performance in exercise and sport. $1^{\text {st }}$ ed. Taylor \& Francis Group: London, UK. 2917; 401.

9. Reilly T, Doran D. Fitness assessment. In: T. Reilly (Ed.), Science and Soccer. $2^{\text {nd }}$ edition. London. 2003; 25-49.

10. Meyer NL, Sundgot-Borgen J, Lohman TG, Ackland TR, Steward AD, et al. Body composition for health and performance: a survey of body composition assessment practice carried out by the Ad Hoc Research Working Group on Body Composition, Health and Performance under the auspices of the IOC Medical Commission. Br J Sports Med. 2013 47: 1044-1053.

PubMed: https://www.ncbi.nlm.nih.gov/pubmed/24065075

11. Reilly $T$, Williams AM, Nevill A, Franks A. A multidisciplinary approach to talent identification in soccer. J Sports Sci. 2000b; 18: 695-702. PubMed: https://www.ncbi.nlm.nih.gov/pubmed/11043895

12. International Society for the Advcance of Kineanthropometric. International Standards for Anthropometric Assessment. The University of South Australia Holbrooks Rd, Underdale, SA, Australia. 2001.

13. Durnin JVGA, Womersley J. Body fat assessed from total body density and its estimation from skinfold thickness: measurement on 481 men and women aged from 16 and 72 years. Br J Nutr. 1974; 32: 77-95. PubMed: https://www.ncbi.nlm.nih.gov/pubmed/4843734

14. Jackson A, Pollock M. Generalized equations for predicting body density of men. Br J Nutr. 1978; 40: 497-504.

PubMed: https://www.ncbi.nlm.nih.gov/pubmed/718832

15. Whiters RT, Craig NP, Bourdon PC, Norton KI. Relative body fat anthropometric prediction of body density of male athletes. Eur J Appl Physiol. 1987; 56: 191-200.

PubMed: https://www.ncbi.nlm.nih.gov/pubmed/3569225

16. Siri W E. Univ. Calif. Radiat. Lab. Publ. №. 3349. 1956.

17. Carter JE. Body composition of Montreal Olympic athletes. In: Carter J, editor. Physical structure of Olympic athletes. Part I The Montreal Olympic Games Anthropological Project. Basel, Switzerland: Karger. 1982; 107-116.

18. Cossio-Bolaños MA, Valdez F, Condori R. Estimación del porcentaje graso a través del método del área superficial en futbolistas. [Estimation of the fat percentage through the surface area method in soccer players]. Memorias VIII Congreso Panamericano de Educación Física. Caracas, Venezuela. 2001.

19. Faulkner J. Physiology of swimming and diving. In: H. Falls (Ed.), Exercise Physiology. Baltimore: Academic Press. 1968; 415-445.

20. Heyward VH, Stolarczyk LM. Body composition basics. In: V.H. Heyward and L.M. Stolarczyk (Eds.), Applied body composition assessment. Champaign IL: Human Kinetics Publishers. 1996; 2-20.

21. Segal $K$, Van Loan M, Fitzgerald $P$, Hodgdon G, Van Itallie B. Lean body mass estimation by bioelectrical impedance analysis: a four site cross validation study. Am J Clin Nutr. 1988; 47: 7-14.

PubMed: https://www.ncbi.nlm.nih.gov/pubmed/3337041

22. Deurenberg P, Van Der Kooij K, Leenen R, Weststrate JA and Seidell JC. Sex and age specific prediction formulas for estimating body composition from bioelectrical impedance: a cross-validation study. Int J Obes. 1991; 15: 17-25.

PubMed: https://www.ncbi.nlm.nih.gov/pubmed/2010255

23. Carter JE, Heath BH. Somatotyping: Development and applications. $1^{\text {a }}$ ed. New York: Cambridge University Press. 1990.

24. Casajús JA, Aragonés MT. Estudio morfológico del futbolista de alto nivel. Composición corporal y somatotipo (parte 1). [Morphological study of high level footballer. Body composition and somatotype]. Arch Med Deporte. 1991; VIII: 147-151.

25. Hencken C, White C. Anthropometric assessment of Premiership soccer players in relation to playing position. Eur J Sport Sci. 2006; 6: 205-211.

26. Arruda M, Cossio-Bolaños MA, Portella D. Los pliegues cutáneos como predictores del porcentaje graso en futbolistas profesionales. [Skinfolds as fat percentage predictors in professional footballers]. Biomecánica. 2009; 17: 38-45.

27. Zuniga U, Osorio A. Somatotipo en jugadores de primera y primera división $A$ pertenecientes a la liga mexicana de fútbol. [Somatotype in first and first division A players belonging to the Mexican football league\}. Ciencia en la frontera: Revista de Ciencia y Tecnología de la UACJ. 2009: VII: 107-112.

28. Hazir T. Physical characteristics and somatotype of soccer players according to playing level and position. J Hum Kinet. 2010; 26: 83-95.

29. Henríquez-Olguín C, Báez E, Ramírez-Campillo R, Cañas R. Perfil Somatotípico del Futbolista Profesional Chileno. [Somatotypic Profile of the Chilean Professional Football Player]. Int J Morphol. 2013; 31: 225-230.

30. Halvorsen Wik E, Mc Auliffe S, James Read P. Examination of physical characteristics and positional differences in professional soccer players in Qatar. Sports. 2019; 7: 9.

PubMed: https://www.ncbi.nlm.nih.gov/pubmed/30602694

31. Leao C, Camoes M, Clemente FM, Nikolaidis PT, Lima R, et al Anthropometric profile of soccer players as a determinant of position specificity and methodological issues of body composition estimation. Int J Environ Res Public Health. 2019; 16: 2386.

PubMed: https://www.ncbi.nlm.nih.gov/pubmed/31284403

32. Herrero A. Cineantropometría: Composición Corporal y Somatotipo de futbolistas que desarrollan su actividad en la Comunidad de Madrid [Cineanthropometry: Body Composition and Somatotype of soccer players who develop their activity in the Community of Madrid] (Unpublished doctoral dissertation). Universidad Complutense de Madrid, Madrid. 2004.

33. Cossio-Bolaños MA, Hespanhol JE, Portella D, Muniz da Silva Y, Pablos Abella $\mathrm{C}$, et al. Valoración de la proporcionalidad de los pliegues cutáneos entre futbolistas profesionales titulares y reservas peruanos. [Evaluation of the proportionality of skinfolds between professional professional players and Peruvian reserves]. Biomecánica. 2013; 21: 30-37.

34. Pau M, Ibba G, Leban B, Scorcu M. Characterization of static balance abilities in elite soccer players by playing position and age. Res Sports Med. 2014; 22: 355-367.

PubMed: https://www.ncbi.nlm.nih.gov/pubmed/25295474

35. Herrero A, Cabañas MD. Evaluación comparativa de la distribución corporal de tejido adiposo entre jugadores de fútbol profesionales, semiprofesionales y amateurs. [Comparative evaluation of the corporal distribution of adipose tissue among professional, semi-professional and amateur soccer players]. Biomecánica. 2003; 11: 23-29. 
36. Cossio-Bolaños MA, Arruda M, Nuñez V, Fama DR, Lancho JL. Propuesta de valores normativos para la clasificación de variables antropométricas en futbolistas profesionales. [Proposal of normative values for the classification of anthropometric variables in professional footballers]. Biomecánica. 2010; 18: 19-23.

37. Do Prado WL, Botero JP, Fernandes Guerra RL, Lopes Rodrigues $C$ and Cuvello LC, et al. Anthropometric profile and macronutrient intake in profesional Brazilian soccer players according to their field positioning. Rev Bras Med Esporte. 2006; 12: 52e-55e.

38. Martin AD, Ross WD, Drinkwater DT, Clarys JP. Prediction of body fat by skinfold caliper. Assumptions and cadaver evidence. Int J Obes. 1985; 9: 31-39.

PubMed: https://www.ncbi.nlm.nih.gov/pubmed/4066123

39. Eston RG, Rowlands AV, Charlesworth S, Davies A, Hoppitt T. Prediction of DXA-determined whole body fat from skinfolds: importance of including skinfolds from the thigh and calf in young, healthy men and women. Eur J Clin Nutr. 2005; 59: 695-702.

PubMed: https://www.ncbi.nlm.nih.gov/pubmed/15798775

40. Rodríguez Gutiérrez C, Echegoyen Monroy S. Características antropométricas y fisiológicas de jugadores de fútbol de la selección mexicana. [Anthropometric and physiological characteristics in elite soccer players]. Arch Med Deporte. 2005; XXII: 33-37.

41. Cossio-Bolaños M, Santi Maria T. Composición corporal de futbolistas profesionales titulares y reservas. [Body composition of professional football players and reserves]. Rev Peru Cienc Act Fís. 2014; 1: 19-25.
42. Gallagher D, Heymsfield SB, Heo M, Jebb SA and Murgatroyd PR, et al. Healthy percentage body fat ranges: an approach for developing guidelines based on body mass index. Am J Clin Nutr. 2000; 72: 694-701. PubMed: https://www.ncbi.nlm.nih.gov/pubmed/10966886

43. Zúñiga $U$, de León LG. Somatotipo en futbolistas semiprofesionales clasificados por su posición de juego. [Somatotype in semiprofessional players classified by their playing position]. Int $\mathrm{J}$ Sports Sci. 2007; 9: 29-36.

44. Almagia A, Araneda A, Sánchez J, Sánchez $P$, Zúñiga $M$, et al. Somatotipo y composición corporal de la selección de fútbol masculino universitario de Chile, Pontifica Universidad Católica de Valparaíso, Campeona los años 2012 y 2013. [Somatotype and body composition of the Chilean men's university football team, Pontifica Universidad Católica de Valparaíso, Champion for the years 2012 and 2013]. Int J Morphol. 2015; 33: $1165-1170$.

45. Esparza Ros F, Alvero Cruz JR. Somatotipo. [Somatotype]. In: F. Esparza Ros (Ed.), Manual de Cineantropometría Madrid: Grupo Español de Cineantropometría. 1ª edición. Monografías FEMEDE. 1993; 25-47.

46. Gil SM, Gil J, Ruiz F, Irazusta A, Irazusta J. Physiological and anthropometric characteristics of Young soccer players according to their playing position: relevance for the selection process. J Strength Cond Res. 2007; 21: 438-445.

PubMed: https://www.ncbi.nlm.nih.gov/pubmed/17530968 